\title{
Research Advances in Allelopathy of Volatile Organic Compounds (VOCs) of Plants
}

\author{
Yiqi Xie ${ }^{1,2}{ }^{\oplus}$, Libo Tian ${ }^{2}$, Xu Han ${ }^{1, *}$ and Yan Yang ${ }^{1, *}$ \\ 1 Tropical Crops Genetic Resources Institute, Chinese Academy of Tropical Agricultural Sciences, \\ Haikou 571101, China; xieyiqi277@163.com \\ 2 College of Horticulture, Hainan University, Haikou 570228, China; faiy7play@163.com \\ * Correspondence: hanxu@catas.cn (X.H.); yangyan@catas.cn (Y.Y.); \\ Tel.: +86-186-8976-3830 (X.H.); +86-135-1803-1806 (Y.Y.)
}

check for updates

Citation: Xie, Y.; Tian, L.; Han, X.; Yang, Y. Research Advances in Allelopathy of Volatile Organic Compounds (VOCs) of Plants. Horticulturae 2021, 7, 278. https:/ / doi.org/10.3390/horticulturae7090278

Academic Editors: Yuyang Zhang and Juan Capel

Received: 4 June 2021

Accepted: 30 August 2021

Published: 2 September 2021

Publisher's Note: MDPI stays neutral with regard to jurisdictional claims in published maps and institutional affiliations.

Copyright: (c) 2021 by the authors. Licensee MDPI, Basel, Switzerland. This article is an open access article distributed under the terms and conditions of the Creative Commons Attribution (CC BY) license (https:/ / creativecommons.org/licenses/by/ $4.0 /)$.

\begin{abstract}
Allelopathy is an ecological phenomenon in which organisms interfere with each other. As a management strategy in agricultural systems, allelopathy can be mainly used to control weeds, resist pests, and disease and improve the interaction of soil nutrition and microorganisms. Volatile organic compounds (VOCs) are allelochemicals volatilized from plants and have been widely demonstrated to have different ecological functions. This review provides the recent advance in the allelopathic effects of VOCs on plants, such as growth, competition, dormancy, resistance of diseases and insect pests, content of reactive oxygen species (ROS), enzyme activity, respiration, and photosynthesis. VOCs also participate in plant-to-plant communication as a signaling substance. The main methods of collection and identification of VOCs are briefly summarized in this article. It also points out the disadvantages of VOCs and suggests potential directions to enhance research and solve mysteries in this emerging area. It is necessary to study the allelopathic mechanisms of plant VOCs so as to provide a theoretical basis for VOC applications. In conclusion, allelopathy of VOCs released by plants is a more economical, environmentally friendly, and effective measure to develop substantial agricultural industry by using the allelopathic effects of plant natural products.
\end{abstract}

Keywords: allelochemicals; VOCs properties; VOCs action; VOCs detection; green agriculture

\section{Introduction}

The concept of "allelopathy" was first proposed by Austrian scientist Hans Molisch in 1937 and mainly referred to the chemical relationship of plant interaction. Allelopathy is an ecological phenomenon and plays an important role in the ecological adaptation of plants [1,2]. The allelopathic effects have both positive and negative effects. Various studies have reported the advantages of allelopathic effects in agricultural systems, such as weed control [3-6], inhibition of pests [7-10], disease [11,12], improvement of soil nutrition $[13,14]$, and microbial interactions $[15,16]$. Ultimately, allelopathy of most plants has effect on plant growth $[10,17,18]$. Plants can synthesize various secondary metabolites during growth and development. Plant VOCs vary by species, and they are related to the abundance of neighboring plant species and plant species composition $[19,20]$. These secondary metabolites can be beneficial or harmful to other organisms when stored or released into the environment, such as secondary metabolites stored in plants that can prevent animal feeding and microbial infestation, while volatiles released into the air can attract insect pollinators [21]. Plants communicate with organisms in the environment through VOCs, thereby achieving a wide range of ecological functions, such as affecting their growth, development, defense, reproduction, and life cycle [22]. In 1984, allelopathy was defined as "any direct or indirect harmful effect by one plant (including microorganisms) on another through production of chemical compounds released into the environment" by Rice [23]. These products of secondary metabolism, called allelochemicals, can be found in any organ of the plant (leaves, stems, flowers, seeds, fruits, and/or roots) and can be released from 
the producing plant by different routes: volatilization, foliar leaching, root exudations, and decomposition of plant residue (Figure 1).

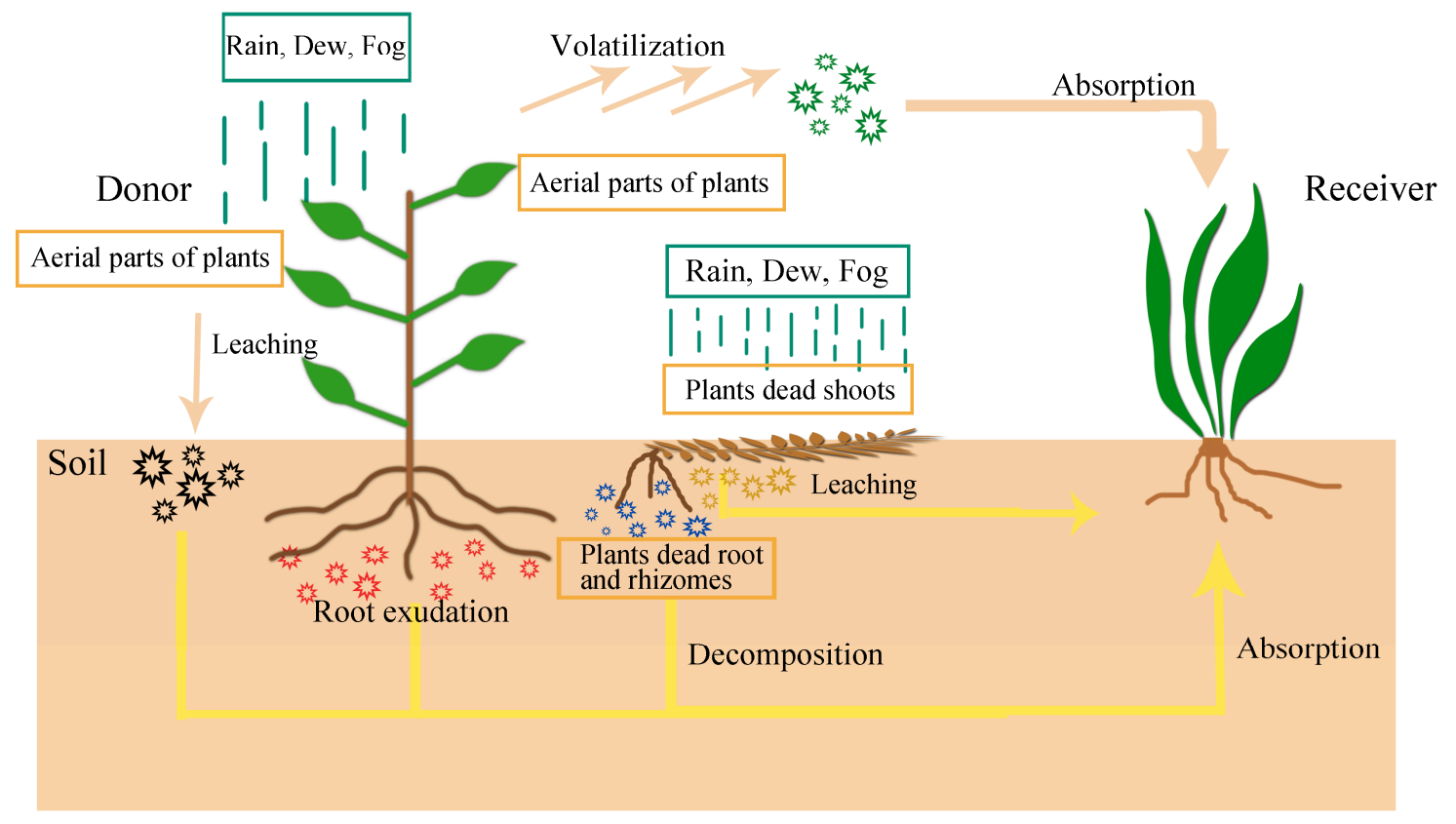

Figure 1. The allelopathy pathways of plants.

VOCs are secondary metabolites volatilized by plants and ubiquitous allelochemicals of plants [24]. Shikimate/phenylalanine, the mevalonic acid (MVA), the methylerythritol phosphate (MEP), and lipoxygenase (LOX) pathways are the four main synthesis pathways of VOCs, and plants can synthesize and release various VOCs including terpenoids, phenylpropanoids/benzenoids, and fatty acid derivatives [25]. The VOCs released by these plants often have different ecological functions, such as chemical communication, kin recognition, attracting or repelling insects, and many other effects [21,26-29]. Although the researches of plants VOCs are mainly aboveground some chemical signal, more and more studies show that VOCs also play an integral part in belowground plant-plant interactions [30]. In fact, the phenomenon that plants release allelochemicals through the volatile pathway has been noticed for a long time. One of the first empirical studies of allelopathy involving VOCs was researched by Molisch, who found that VOCs released by apples and pears could inhibit potato germination [31]. VOCs have been widely demonstrated to defend primarily against herbivorous insects [32,33], microbes, and pathogens [34-36], thereby reducing extreme environmental stress $[37,38]$ and promoting nutritional acquisition [11]. Muller et al. [39] researched the volatiles of annual grassland species in Salvia leucophylla Greene and Artemisia californica communities, and this revealed that volatile allelochemicals had the interspecific allelopathic effects on the woody herbaceous plants, which would negatively affected the recipient plant species $[40,41]$ and changed soil microorganisms [42,43]. Besides, in addition to VOCs released from plant shoots, root volatiles may also have allelopathic effects on neighboring plants; for example, VOCs from big sagebrush (Artemisia tidentata Nutt.) root inhibited seed germination of wild tobacco (Nicotiana attenuata) [44]. Most allelochemicals produced by plant roots are considered as "root exudates" [45], but the few allelochemicals released by volatilization of roots are called VOCs, which play an important ecological role in the soil ecosystem and have not been studied thoroughly $[46,47]$.

Allelopathy has received high attention and become one of the central scientific problems in ecology [48]. Allelopathy is forming an independent scientific system, and we are conducting in-depth and extensive research from both theoretical and practical aspects. VOCs released by plants are one of the main ways to achieve allelopathic effects. It is a more 
economical, environmentally friendly, and effective measure to use the allelopathic effect of plant natural products to develop the agricultural production [49]. Several excellent reviews have summarized the relevant research on potential applications of VOCs $[20,22,49]$, but the studies on allelopathy of plants VOCs have not been systematically reviewed and reported. VOCs are a kind of natural and environmentally friendly chemical substances that volatilize from plants and are used as natural herbicides and fungicides to protect neighboring plants from stress and increase crop yields [49]. We think VOCs have a much broader range of the potential applications. So, in this context, study on the allelopathy of VOCs is particularly important to the future development of green agriculture. The review mainly focuses on the recent studies of allelopathy of plants VOCs, regarding resisting diseases and preventing pests of plant, impacting on competition (inhibiting weed hazards), breaking dormancy, regulating plant growth, affecting reactive oxygen species (ROS) content and enzyme activity, modulating plant respiration and photosynthesis, and their role as a signal conducting substance. We present the evidence from the references to illustrate these roles to deepen the understanding of allelopathy of plants VOCs.

\section{Allelopathy of VOCs of Plants}

With the increasing attention of experts on the allelopathy of volatile, the potential role of VOCs in agriculture has been gradually discovered. The allelopathy of VOCs on plants are summarized based on existing research, which involved the main allelopathy of plant VOCs. (Figure 2).

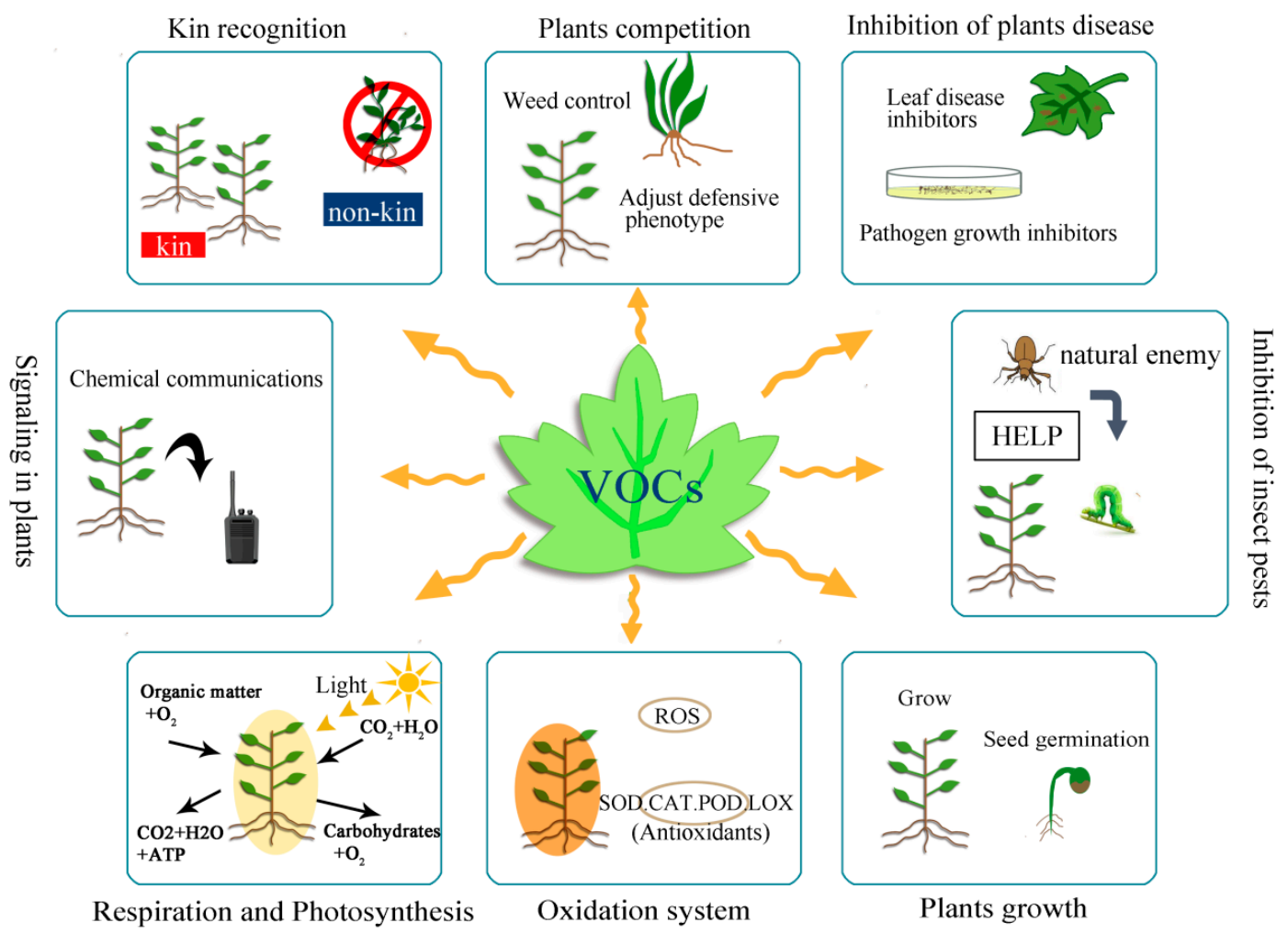

Figure 2. The main allelopathy of plants VOCs. (Note: This figure is widely inspired and adapted from Brilli et al. (2019) [49]).

\subsection{VOCs and Plants Growth}

Numerous results showed that VOCs have an effect on plant cell growth and differentiation [50-53], such as diallyl disulfide (DADS) of garlic VOCs, which can affect mitotic activity and cell length of tomato roots by impacting on cell division, endogenous plant hormone levels, expansin gene expression, and sulfate assimilation and glutathione (GSH) metabolism [53,54]. 
Similarly, many studies confirm that plant volatiles can inhibit seed germination and the growth of root and seedling [50,55-60]. $\beta$-terpineol, linalool, eugenol, and tetradecanoic acid are the VOCs released from tomato (Solanum lycopersicon Mill.) foliage, and they could inhibit seed germination of the tropical plant Amaranthus mangostanus L. [55]. The brassica species exude allelochemicals, which are glucosinolates [61] that could break down into several biological action compounds, such as isothiocyanates, which have biologically active and inhibit germination and growth of exposed plant species [57,62]. VOCs released from pine needles and the roots of Pinus halepensis L. mainly inhibited the seed germination and root growth of two herbaceous target species Lactuca sativa L. and Linum strictum L. [63]. VOCs affect plant growth, mainly to change plant morphology and reduce plant biomass. Therefore, seed germination, seedling root length, and seedling height are often used as intuitive indicators to evaluate allelopathy. Low concentrations of DADS promoted the growth of cucumber roots and induce elongation of the main roots by up-regulating the expression of CsCDKA and CsCDKB genes and regulating the hormone balance of the roots [64]. The VOCs released by Atriplex cana Ledeb. (Amaranthaceae) significantly inhibited seedling growth of Amaranthus retroflexus L. and Poa annua L., and $5 \mu \mathrm{g} / \mathrm{mL}$ essential oil completely inhibited the seed germination of $A$. retroflexus, Medicago sativa L., P. annua, and Echinochloa crusgalli L. [65]. Besides, Effah et al. found that plant VOCs mediate multiple ecological networks, and they may mediate the allelopathic effects of the germination or growth of competitors seeds [66]. Monoterpenoids are considered as effective inhibitors of seed germination and seedling growth $[67,68]$.

VOCs affect plant growth, mainly to inhibit plant growth, but some studies have found that VOCs have dual effects on germination and plant growth, both promoting and inhibiting; for example, Arroyo et al. found that volatile chemicals from Artemisia herba-alba Asso. inhibited the germination of Pinus halepensis Mill. seeds, promoted the growth of $P$. halepensis seedlings, and reduced the root biomass of Salsola vermiculata L. seedlings [69]. VOCs also have an effect on plants growth direction. Runyon et al. found that Cuscuta pentagona seedlings were favored by not only the growth of host tomato plants, but also the direction of tomato VOCs [70]. The extracted VOCs of tomato and wheat were placed on both sides of $C$. pentagona seedlings, and the $C$. pentagona seedlings continued to grow in the direction of tomato VOCs. It was also found that $\beta$-phellandrene and $\beta$-myrcene of tomato VOCs could significantly attract the growth of $C$. pentagona seedlings.

\subsection{VOCs and Weed Control}

Allelopathy gain extensive attention in biological weed control [3-6,71]. Boydston et al. [3] found that mustard seed meal has the potential for weed control in organic production systems. The release of volatile organic compounds from the leaves can cause allelopathic effects and damage the growth of other competitive plants [72]. The allelopathy of the volatile allelochemicals may perform a vital part in inhibiting the competitive ability of weed species, be one of the alternatives to control weed infestation, and it has excited the greatest interest [67,73-75]. Therefore, the best way to control weeds is to use the crops' own competition and allelopathy. Wei et al. reported that the volatile oil released by Atriplex cana Ledeb. significantly inhibited the growth of seedlings of four weed species, including Amaranthus retroflexus L. and Poа annua L., and it had a high value for further use as a biological herbicide [65].

Brassicas produce the allelochemicals glucosinolates throughout their plant parts and released them into the environment by volatilization [76]. In the natural environment, glucosinolates are broken down into several compounds, and the most important compound of them is isothiocyanate [77], which can inhibit the growth and development of plant or weed [78]. Digitaria sanguinalis is a common non-irrigated weed that severely affects crop yields. Pardo-Muras et al. showed that the oxygenated monoterpenes in VOCs produced and released by both Ulex europaeus and Cytisus scoparius inhibited the germination and early growth of two weeds, A. retroflexus and D. sanguinalis [79]. Many studies have reported that in addition to independent effects of VOCs, VOCs also have 
synergistic or antagonistic effects. These synergistic and antagonistic effects lead to the final allelopathy $[80,81]$.

Besides, VOCs from invasive species can also reduce interspecific performance and improve the performance of invasive species [82]. VOCs might also be perceived by neighboring plants to adjust their defensive phenotype according to the present risk of attack. Allelochemicals as natural herbicide have an attractive prospect, and some plants may be expected to develop into a new generation of herbicides or fungicides.

\subsection{VOCs and Plants Dormancy}

Dormancy is a physiological state in which plants respond to stress [83]. DADS is considered as main allelochemical of VOCs in garlic [53]. Hosoki et al. reported that the sulfur-containing compounds from garlic VOCs could break the bud dormancy in some corms, tubers, and ornamental trees [84,85]. Kubota et al. found that exposure to volatile diallyl disulfides and trisulfides was the most effective treatment to promote the bud break of single-bud cuttings of "Kyoho" (Vitis vinifera $\times$ labruscana Bailey) [86]. So, the allelochemicals in garlic that break the dormancy of vine buds are sulfur compounds, particularly DADS. In addition to DADS, more and more studies can prove that VOCs can affect plant dormancy. In a recent study, Shukla et al. studied the breaking dormancy of potato tubers effects on 20 essential oils from medicinal and aromatic plants [87]. The essential oils could induce or inhibit the sprouting process of potato tubers by altering the accumulation of reducing sugars, ethylene production, and expression of genes, thereby affecting the dormancy of plants [87]. Besides, eugenol from clove essential oil and carvone from caraway and dill essential oils have been reported to inhibit potato tubers sprouting [88-90]. The results showed that the essential oils of lemon grass and clove were the most effective VOCs for breaking dormancy and inducing germination of potato tubers. The oils of palmarosa and ajwain inhibited the sprout of potato tubers [87]. Owolabi et al. found the essential oils of Lippia multiflora, Cymbopogon citratus, and Zingiber officinale could control potato tubers dormancy [91]. They are suitable for application as sprout suppressants. At present, there are few studies on the effects of VOCs on plant dormancy, and the specific mechanism of action needs to be studied in the future.

\subsection{VOCs and the Inhibition of Plants Diseases and Insect Pests \\ 2.4.1. Inhibition of Plants Disease}

VOCs not only have an inhibitory effect on plants, but also on pathogenic bacteria. A number of experimental trials showed that leaves' VOCs inhibited germination and the growth of plant pathogens and had stronger activity than commercial fungicides [92-94]. The essential oil of oregano triggers the expression of hundreds of genes involved in the grapevine immune system, so it can prevent Plasmopara viticola infection in grapevine (Vitis Vinifera) and primes plant immunity mechanisms [95]. The inhibition rate of volatile allelochemicals from leaves of Ocimum adscendens to 29 different kinds of mycelium was over $98 \%$, and the inhibition rate of mycelium growth of Aspergillus reached 100\%; especially, the activity of $A$. lavus was 10 100 times higher than another five commercial fungicides [96]. Chaturvedi et al. found that volatiles released by Adenocalymma allicea could effectively control leaf spot in rice and kill the pathogenic fungus Drechslera oryzae. When volatile oil obtained from A.alicea plants compared with the activity of the synthetic fungicides blitox-50 and $\mathrm{m}-45$, the activity of volatile oil to $D$. oryzae was up to four times higher than those synthetic fungicides [97]. In particular, this volatile oil had no harmful effect on the growth and development of rice seedlings. The volatile oil released from the leaves of the same genus Ocimum basilicum also inhibited the growth of other fungal mycelia by more than $85 \%$, and the dosage was only $1 / 4$ of the commercial fungicide [98]. Therefore, using VOCs to replace commercial fungicide is no longer a dream. Phenols are a kind of allelochemicals that have been concerned and studied. Eugenol is an important class of phenolic allelochemicals. Cloves have a long history of use, and the main volatile component eugenol has a strong inhibitory effect on fungi and bacteria $[99,100]$. 
In a recent study, Quintana-Rodriguez et al. performed a screening on the efficacy of 22 VOCs, which were known to be volatilized from infected plants leaves, against the fungal pathogens Colletotrichum lindemuthianum, Fusarium oxysporum, and Botrytis cinerea. The work results showed that nonanal, (+)-carvone, citral, trans-2-decenal, L-linalool, nerolidol, and eugenol significantly inhibited the growth of the three fungal species, and eugenol had the most active among them. Therefore, the VOCs of plants have the disease resistance function [101].

In addition to eugenol, there are many VOCs that can also inhibit pathogens. DADS is a volatile organosulfur compound derived from garlic (Allium sativum L.) bulbs, and it is known as an allelochemical because of the potential allelopathy of garlic. A large number of study results show that it has a strong inhibitory effect on a variety of pathogenic bacteria [102]. In a recent study, Yang et al. demonstrated that the VOCs (DADS) from green garlic (Allium sativum L.) increased the accumulation of $\mathrm{H}_{2} \mathrm{O}_{2}$ and the disease resistance of cucumber [103]. Sekine et al. reported that other VOCs such as cuminaldehyde and $p$-cymene also have been demonstrated to possession antifungal activity against $B$. cinerea, F. oxysporum, Verticillium dahliae, and Alternaria mali [104]. According to the work of Mandal and Mandal, linalool, a substance with antifungal and antioxidant potential, was found in the volatile oil of coriander (Coriandrum sativum L.) [105].

\subsubsection{Inhibition of Plants Insect Pests}

Numerous studies showed that plants not only produce toxins and hormones directly in response to insect feeding, but also release VOCs to attract predators [106,107]. A class of VOCs produced as a response to herbivore attacking are mainly terpenoids, predominantly monoterpenoids, and sesquiterpenoids [107], and they benefited the host plant by interacting with herbivores. For example, when the larva of Spodoptera exigua Hübner. were feeding on corn, the corn released volatile terpenoids to attract the parasitic wasp, which was the natural enemy of S. exigua. If it was not mechanically damaged, the corn did not release VOCs to attract the natural enemy. Further studies found that the oral saliva of the beet moth contained volicitin, when the beet moth bit corn, its messenger jasmonic acid derivatives were activated by volicitin to release terpenoids to lure Cotesia marginiventris Cresson [108]. Kessler and Baldwin found that wild tobacco could release VOCs to attract mealoptera, the natural predators of caterpillars, when caterpillars ate them. Additionally, the VOCs released by wild tobacco also could prevent caterpillars from laying eggs on the leaves [21].

Under natural conditions, plants can also achieve effective control of related pests by releasing volatile substances to attract natural enemies. It is confirmed that the indirect chemical defense of plants by releasing VOCs to attract natural enemies is a chemical relationship in nature. Ageratum conyzoides L. released volatile terpenoid into the air by stalks, leaves, and flowers to attract predatory mites (Amblyseius SPP.) and maintain their population density [26]. Predatory mites are the most effective natural enemies of red mites (Panonychus citri). So, the population density of red mites was reduced [26]. Degenhardt et al. found that VOCs from corn root (E)-b-caryophyllene attracted insectkilling nematodes to control a major pest [109]. Therefore, the sustainable control of pests and diseases can be achieved through the natural chemical mechanisms that exist in the field to regulate plant-organism interactions. As a natural fungicide, VOCs have no harmful effect on plant growth and development, and using VOCs is a more environmentally friendly and economical way to kill bacteria.

\subsection{VOCs and Plants Respiration and Photosynthesis}

Previous studies showed that allelochemical can affect plant respiration by interfering in various stages of respiration, including the generation of carbon dioxide $\left(\mathrm{CO}_{2}\right)$ by electron transport, oxidative phosphorylation, and the activity of ATPase, and it has the potential to inhibit plant growth and development [41,110,111]. VOCs released from the leaves of A. tridentata Nutt. var. vaseyana and Sasa cernua Makino. inhibited the respiration 
of germinating seeds $[110,112]$. In fact, studies of allelopathy processes in shrubs in the 1960s found that volatile terpenes could reduce respiration in the young leaves of some plants and increase respiration in mature leaves [113]. Similarly, terpenes in eucalyptus volatile oil could affect target plants by inhibiting cellular respiration [114]. The influence mechanism of these allelochemicals on plant respiration deserves more in-depth study.

In addition, photosynthesis plays an important role in realizing the energy conversion in nature and maintains the carbon-oxygen balance in the atmosphere. The high concentration of allelochemicals involved in multiple metabolic steps may lead to the inhibition of plant photosynthesis, or even block the mechanism of photosynthesis by inhibiting electron receptors, energy coupling, or destroying photosynthetic pigments and enzymes [115]. Isoprene volatilized from the foliage of many woody species was thought to increase the rate of photosynthesis by stabilizing thylakoid membranes, so that adjacent plants could tolerate high temperatures [116]. Kaur et al. found the volatile oils $\alpha$-Pinene and 1,8-cineole from Eucalyptus tereticornis $\mathrm{Sm}$. could significantly reduce the respiration and photosynthetic pigment content of Amaranthus viridis Linn. Seedlings; thereby, the negative effects of the oil on photosynthetic machinery was explained [117]. These studies can confirm that olefin compounds can affect the photosynthesis of plants. In addition, Tsubo et al. found that exposure to low concentrations of the volatile chemicals released by $A$. adamsii Besser stimulated the photosynthetic rates of Stipa krilovii Roshev [118]. The volatile oil of Artemisia ordosica Krasch. inhibited the growth and photosynthesis of Palmellococcus miniatus through oxidative damage [119]. Zhao et al. studied the effects of eucalyptol and limonene, the main terpenoids in cyanobacteria VOCs on the photosynthetic capacity of Chlorella vulgaris [120]. The results showed that the compounds could induce the degradation of photosynthetic pigments and reduce the photosynthetic abilities of other algae. These studies can confirm that VOCs have the ability to affect plant photosynthesis.

\subsection{VOCs and Plants ROS Content and Enzymatic Activity}

Reactive oxygen species (ROS) play a vital role in the plant defense against stresses. The balance between ROS generation and scavenging is considered as paramount in cellular homeostasis. In recent years, more and more attention has been paid to the effectiveness and feasibility of monomer organic sulfide extracted from garlic as an anti-tumor drug, and the research and development of monomer organic sulfide has become an important research topic [121]. Similarly, DADS had an effect on the ROS content of plants. Yang et al. used cucumber and garlic as test materials to study the allelopathy of VOCs from green garlic on the scavenging of cucumber ROS [103]. The results showed that DADS, a volatile substance in garlic, reduced superoxide anions and increased hydrogen peroxide accumulation in cucumber seedlings. The effects of VOCs on antioxidant enzymatic activities were species dependent. They can regulate the activity of antioxidant enzymes (SOD, CAT, and POD) of cucumber seedlings in response to oxidative stress. VOCs released from Acacia dealbata Link. leaves increased the activity of superoxide dismutase (SOD) and peroxidase (POD) in L. multiflorum flowers, but decreased SOD activity in T. subterraneum [60]. The volatile allelochemical myrcene rapidly induced ROS production and significantly increased the activity of lipoxygenase (LOX) in rice roots [122]. In other cases, Mutlu et al. reported that the aerial parts of Nepeta meyeri Benth. contained two volatile oils, Germacrene-d and Caryophyllene oxide, and they could reduce the SOD activity of six weed species [123]. Jin et al. reported that the essential oil such as carvacrol, cinnamaldehyde, perillaldehyde, and linalool enhanced the SOD and POD activities of Chinese bayberries, and carvacrol had the best effect [124].

\subsection{VOCs and Plants Signal Transduction}

\subsubsection{Chemical Communications}

Plants, similar to animals, do not exist in isolation. Plant individuals and populations maintain population relationships and resist external stress through chemical communication. VOCs volatilized from some plants are involved in plant-plant communication. 
Through more than 20 years of research, it has been found that when plants were stressed by insect feeding, microbial infection, and mechanical damage, they could use volatile organic substances to carry out inter-chemical and intra-chemical chemical communication $[125,126]$. Plants sent VOCs signals under attack or stress, then neighboring plants received these VOCs signals directly or indirectly to turn on the chemical defense mechanisms and produce phenolic alkaloids chemical defense compounds including directly terpenoids and other defense substances. Indirect chemical defense the use of VOCs to attract the natural enemies of pests, through the methods of predation and parasitism to eliminate pests. For example, the VOCs signals released by injured $A$. tidentata could induce direct chemical defense by protease inhibitors in Nicotiana attenuate, and the VOC signals released by maize leaves when insects fed could induce plants to rapidly release monoterpenoids that attracted insect predators for indirect defense [127,128]. Wild lima bean quickly synthesized and secreted excess nectar to attract natural enemies after receiving VOC signals from plants that have been harmed by foraging [129]. In recent years, more and more research has gone deep into the mechanism of action of these chemical communication signaling molecules. Baldwin et al. [125] found when in response to the attack, infested leaves released (E)- $\beta$-ocimene (typical signaling chemicals of volatile terpenoids) to increase the resistance of un-infested leaves and induce the expression of defense-related genes in neighboring un-infected leaves [130]. In future research, based on the clarification of the biochemical and metabolic processes of the phytochemical signal substances that have been discovered, the response mechanism of the recipient plants to these signal substances should be further explored. Therefore, although the research of phytochemical communication faces huge challenges, the clarification of phytochemical identification and communication relationships will broaden the horizons of the interspecific and intraspecific relationships of plants.

\subsubsection{Plant Kin Recognition}

Kin recognition is simply the ability of an individual to distinguish the relationship between genetically close related kin and non-kin. The kin recognition of plants has very important ecological and evolutionary significance. Increasing evidence shows that plants recognition of neighboring allogenous and heterogeneous plants is mostly mediated by chemicals [131,132]. When plants are attacked by herbivores, they will emit volatile signals to surrounding plants. Some plants, such as A. tidentata, suffered less damage than other plants that receive volatile signals from non-self-wounds $[133,134]$. This shows that VOCs play a role in plant self- and non-self-recognition. Because VOCs are the simplest and fastest chemical signal that can send to neighboring plants, plant recognition of volatiles helps plants to establish corresponding response strategies in the early stages of competition. This can avoid wasting resources in the competition between self and relatives as much as possible [130]. After a series of studies recently, although the kin recognition of plants is ubiquitous, most studies show that some plants do not have kin recognition behaviors in order to avoid meaningless competition [27,135-137]. Plants' kin recognition has always been a hot topic in the study of behavioral ecology and evolution. From the perspective of genetic recognition, it is of great theoretical and practical significance to re-examine the ecological interaction of individual crops and groups and the environment.

\section{Method of VOCs Collection and Identification}

The allelopathy of VOCs has attracted widespread attention in recent years and a lot of research work has been done. With the advancement of organic separation and identification technology and the participation of more and more experts, the collection and identification technology of plants VOCs is no longer a difficult issue in research.

\subsection{Collection of Plants VOCS}

The volatiles mostly are organic compounds with a molecular weight between 100 and 200, such as hydrocarbons, alcohols, ketones, organic acids, nitrogen compounds, and 
organic sulfur [138]. Most of them have high chemical activity. Different collection methods may directly affect the type and proportion of VOCs, so it is particularly important to choose the appropriate method.

Traditional distillation collection techniques include steam distillation (SD), simultaneous distillation and solvent extraction (SDE), microwave-assisted hydrodistillation extraction (MWHD), ultrasound-assisted extraction (USE), and solid-phase trapping solvent extraction (SPTE). They have certain disadvantages in the isolation and purification of chemical constituents from plants tissues, such as long extraction time, high volumes solvent, and low efficiency [139]. In addition, many natural products are thermally unstable and may degrade during thermal extraction or distillation.

The most mainstream approach is headspace solid-phase microextraction (HS-SPME). It has some advantages over SD, SDE, and SPTE, such as rapid solvent-free extraction, no apparent thermal degradation, less laborious manipulation and sample requirement, and so on [140]. Moreover, due to the relatively low temperature and short headspace solid-phase extraction time, the risk of thermal artifacts is extremely low compared to other techniques [141]. Additionally, it is easy to standardize and fully integrate into the analysis system [142]. Thus, HS-SPME is an ideal technology of plants' VOC collection.

\subsection{Identification of Plants VOCs}

Identification of allelochemicals involves both quantitative and qualitative measurement. Qualitative identification is the identification of the type and structure of the allelochemicals. Qualitative identification involves methods such as gas chromatography (GC), mass spectrometry (MS), nuclear magnetic resonance (NMR), Fourier transform infrared (FT-IR) spectroscopy, and many other methods [143-145]. These are the analysis methods of VOCs, but the analytical difficulties and required instruments are completely different. Quantitative identification means the determination of the concentration of allelochemicals on the premise of clarifying the type of them. The method of chromatography is used to detect the concentration of known substances. Different methods should be selected for qualitative and quantitative identification, and the selection criteria are determined according to the characteristics of VOCs.

The existing identification techniques include gas chromatography mass spectrometry (GC-MS), high-performance liquid chromatography (HPLC), proton-transfer-reaction mass spectrometry (PTR-MS), and so on. PTR-MS has the potential to sample VOCs on-line and make quantitative analysis fast without any sample preparation $[146,147]$. The most widely used of these identification techniques is GC-MS [148]. Although PTR-MS can better achieve quantitative identification, most of the volatiles identified are preliminary [149]. GC-MS has a higher selectivity and sensitivity in the identification of VOCs and efficient separation and identification of the analytes.

\section{Conclusions}

This review summarizes the allelopathy of VOCs of plants including growth, competition, dormancy, resistance of pests and diseases, respiration, photosynthesis, ROS content, enzyme activity, and signaling. It also summarizes the main methods of collection and identification of VOCs. The study of allelopathy is quite a complicated work, because it involves a variety of disciplines such as chemistry, ecology, biology, microbiology, and so on. Scientists in these fields need to work together to conduct research. The study of allelopathy on plants VOCs is still a new field. Most of the researches still focus on the expression of the allelopathic phenomenon, but the depth and breadth of them are far from enough, such as the lack of research on allelopathy mechanisms of plants, the relationship between chemical recognition and communication mechanisms and allelopathy mechanisms, and so on. In recent years, we have seen more and more reports on VOCs. VOC transmission, emission, and accumulation are also hot topics in research, which deserve more research attention. There are still many issues that need to be further explored. Plant VOCs deserve more research attention. 


\section{Prospective}

VOCs may have a wide range of potential allelopathic effects in agriculture. VOCs can not only manage weeds and pests as natural substance, but also regulate plant growth, competition, dormancy, respiration and photosynthesis, ROS content, enzyme activity, and diseases resistance. The most important thing is that they come from plants and meet our requirements for developing green agriculture. It has more economic value and is a more environmentally friendly and effective measure to use the allelopathic effects of plant natural products to develop agricultural industry. At the same time, there are some limitations in using allelopathy of VOCs of plants; for example, in field trials, VOCs are not easy to control. The volatilization of VOCs of plants is specific to species, cultivars, genotypes, and organs, as well as environments. In fact, the release of VOCs by plants are not single VOCs, but a complex mixture [150]. In agricultural production, the release of plant VOCs is affected by environmental and meteorological conditions, such as wind speed and direction, humidity and rain, and temperature, among others. These factors make the release of VOCs difficult to control. Moreover, the concentration of VOCs in open field experiments is often lower than in laboratory experiments. Therefore, the allelopathy of plant VOCs in agricultural production is more suitable for an easily controlled greenhouse.

With the development of allelochemicals identification technology and the participation of more and more chemists, the identification of allelochemicals is no longer a difficult problem in the study of allelopathy. However, the molecular mechanism of VOCs has not been studied, and it is not yet clear how VOCs are perceived by plants, and little is known about the dynamics of the active release pathway of VOCs of plants. Therefore, the focus of future research is to explore the nature and regularity of plant VOCs allelopathy and dynamic process of VOCs release, mainly to decipher the perception mechanism of VOCs within plant tissues. Over the past ten years, a large number of studies have proved that VOCs are involved in signal transduction among plants, and many allelochemicals involved in chemical communication have been identified. Now the problem we are facing is how the mechanism of chemical recognition and communication and the mechanism of allelopathy interacts. The general and specific chemical identification and the research on the identification and transfer mode of the communicating substance are urgent issues to be solved. Because the VOCs of plants are not easy to control, identifying the natural concentration of VOCs is also a major problem we face with.

At present, with increasing demands for environmental protection and sustainable development, VOCs have a dominant position in agricultural development and will become more competitive in the future, especially in the greenhouse. The theoretical research and practical application of allelopathy of plants VOCs have profound significance for sustainable development of agricultural production, for maintenance and improvement of natural resources, and for the rational arrangement of rotation and intercropping, the construction of efficient planting systems, and the improvement of natural resources' utilization efficiency, for the construction of efficient planting systems and rational arrangement of rotation and intercropping or controlling pests and weeds. Not only that, the use of allelopathy of plant volatiles can also affect plant life activity by regulating plant growth, dormancy, respiration and photosynthesis, ROS content, and enzyme activity, or by the chemical communication between plants. In summary, the allelopathy of VOCs of plants has inestimable potential in agricultural development. Based on this, it is of great significance to develop and practice the application potential of allelopathy of plant VOCs.

Author Contributions: Writing-review and editing, Y.X., X.H. and L.T.; funding acquisition, X.H. and Y.Y. All authors have read and agreed to the published version of the manuscript.

Funding: This study was funded by the Youth Program of National Natural Science Foundation of China (No. 31601747), High-Level Talents Project of Hainan Natural Science Foundation (No. 320RC723), Innovation Team Project of Chinese Academy of Tropical Agricultural Sciences (No. 1630032017029), Departmental Budget Project of Ministry of Agriculture and Rural Affairs 
of the People's Republic of China, and Major Science and Technology Project in Hainan Province (No. ZDKJ2017001).

Institutional Review Board Statement: Not applicable.

Informed Consent Statement: Not applicable.

Acknowledgments: We acknowledge Ziji Liu for comments on a previous version of the manuscript.

Conflicts of Interest: The authors declare that they have no conflict of interest.

\section{References}

1. Farooq, M.; Jabran, K.; Cheema, Z.A.; Wahid, A.; Siddique, K.H.M. The role of allelopathy in agricultural pest management. Pest Manag. Sci. 2011, 67, 493-506. [CrossRef] [PubMed]

2. Pan, L.; Li, X.-Z.; Yan, Z.-Q.; Guo, H.-R.; Qin, B. Phytotoxicity of umbelliferone and its analogs: Structure-activity relationships and action mechanisms. Plant Physiol. Biochem. 2015, 97, 272-277. [CrossRef] [PubMed]

3. Boydston, R.A.; Morra, M.J.; Borek, V.; Clayton, L.; Vaughn, S.F. Onion and weed response to mustard (Sinapis alba) seed meal. Weed Sci. 2011, 59, 546-552. [CrossRef]

4. Awan, F.K.; Rasheed, M.; Ashraf, M.; Khurshid, M.Y. Efficacy of brassica sorghum and sunflower aqueous extracts to control wheat weeds under rainfed conditions of pothwar. Pakistan J. Anim. Plant Sci. 2012, 22, 715-721.

5. Bajwa, A.A.; Mahajan, G.; Chauhan, B.S. Nonconventional weed management strategies for modern agriculture. Weed Sci. 2015, 63, 723-747. [CrossRef]

6. Tavella, L.B.; Lima e Silva, P.S.; Monteiro, A.L.; de Oliveira, V.R.; de Oliveira Fernandes, P.L. Gliricidia sepium intercropping for weed management in immature corn ear production. Rev. Cienc. Agron. 2017, 48, 650-656. [CrossRef]

7. Avato, P.; D’Addabbo, T.; Leonetti, P.; Argentieri, M.P. Nematicidal potential of brassicaceae. Phytochem. Rev. 2013, 12, 791-802. [CrossRef]

8. Liu, T.; Cheng, Z.; Meng, H.; Ahmad, I.; Zhao, H. Growth, yield and quality of spring tomato and physicochemical properties of medium in a tomato/garlic intercropping system under plastic tunnel organic medium cultivation. Sci. Hortic. 2014, 170, 159-168. [CrossRef]

9. Glinwood, R.; Ninkovic, V.; Pettersson, J. Chemical interaction between undamaged plants—Effects on herbivores and natural enemies. Phytochemistry 2011, 72, 1683-1689. [CrossRef]

10. Singh, A.; Weisser, W.W.; Hanna, R.; Houmgny, R.; Zytynska, S.E. Reduce pests, enhance production: Benefits of intercropping at high densities for okra farmers in Cameroon. Pest Manag. Sci. 2017, 73, 2017-2027. [CrossRef]

11. Bertin, C.; Yang, X.; Weston, L.A. The role of root exudates and allelochemicals in the rhizosphere. Plant Soil 2003, $256,67-83$. [CrossRef]

12. Abdel-Monaim, M.F.; Abo-Elyousr, K.A.M. Effect of preceding and intercropping crops on suppression of lentil damping-off and root rot disease in New Valley-Egypt. Crop Prot. 2012, 32, 41-46. [CrossRef]

13. Ma, Y.-h.; Fu, S.-l.; Zhang, X.-p.; Zhao, K.; Chen, H.Y.H. Intercropping improves soil nutrient availability, soil enzyme activity and tea quantity and quality. Appl. Soil Ecol. 2017, 119, 171-178. [CrossRef]

14. Ndungu-Magiroi, K.W.; Wortmann, C.S.; Kibunja, C.; Senkoro, C.; Mwangi, T.J.K.; Wamae, D.; Kifuko-Koech, M.; Msakyi, J. Maize-bean intercrop response to nutrient application relative to maize sole crop response. Nutr. Cycl. Agroecosyst. 2017, 109, 17-27. [CrossRef]

15. Bressan, M.; Roncato, M.-A.; Bellvert, F.; Comte, G.; Haichar, F.e.Z.; Achouak, W.; Berge, O. Exogenous glucosinolate produced by Arabidopsis thaliana has an impact on microbes in the rhizosphere and plant roots. Isme J. 2009, 3, 1243-1257. [CrossRef]

16. Zhao, M.; Jones, C.M.; Meijer, J.; Lundquist, P.-O.; Fransson, P.; Carlsson, G.; Hallin, S. Intercropping affects genetic potential for inorganic nitrogen cycling by root-associated microorganisms in Medicago sativa and Dactylis glomerata. Appl. Soil Ecol. 2017, 119, 260-266. [CrossRef]

17. Farooq, M.; Bajwa, A.A.; Cheema, S.A.; Cheema, Z.A. Application of allelopathy in crop production. Int. J. Agric. Biol. 2013, 15, 1367-1378.

18. Alemayehu, A.; Tamado, T.; Nigussie, D.; Yigzaw, D.; Kinde, T.; Wortmann, C.S. Maize-common bean intercropping to optimize maize-based crop production. J. Agric. Sci. 2017, 155, 1124-1136. [CrossRef]

19. Vivaldo, G.; Masi, E.; Taiti, C.; Caldarelli, G.; Mancuso, S. The network of plants volatile organic compounds. Sci. Rep. 2017, 7, 11050. [CrossRef] [PubMed]

20. Kigathi, R.N.; Weisser, W.W.; Reichelt, M.; Gershenzon, J.; Unsicker, S.B. Plant volatile emission depends on the species composition of the neighboring plant community. BMC Plant Biol. 2019, 19, 58. [CrossRef]

21. Kessler, A.; Baldwin, I.T. Defensive function of herbivore-induced plant volatile emissions in nature. Science 2001, 291, 2141-2144. [CrossRef] [PubMed]

22. Bouwmeester, H.; Schuurink, R.C.; Bleeker, P.M.; Schiestl, F. The role of volatiles in plant communication. Plant J. 2019, 100, 892-907. [CrossRef] [PubMed]

23. Rice, E.L. Allelopathy, 2nd ed.; Academic Press: Orlando, FL, USA, 1984. 
24. Adebesin, F.; Widhalm, J.R.; Boachon, B.; Lefevre, F.; Pierman, B.; Lynch, J.H.; Alam, I.; Junqueira, B.; Benke, R.; Ray, S.; et al. Emission of volatile organic compounds from petunia flowers is facilitated by an ABC transporter. Science 2017, 356, 1386-1388. [CrossRef]

25. Dudareva, N.; Klempien, A.; Muhlemann, J.K.; Kaplan, I. Biosynthesis, function and metabolic engineering of plant volatile organic compounds. New Phytol. 2013, 198, 16-32. [CrossRef] [PubMed]

26. Kong, C.; Hu, F.; Xu, X.; Zhang, M.; Liang, W. Volatile allelochemicals in the Ageratum conyzoides intercropped citrus orchard and their effects on mites Amblyseius newsami and Panonychus citri. J. Chem. Ecol. 2005, 31, 2193-2203. [CrossRef]

27. McNickle, G.G.; St Clair, C.C.; Cahill, J.F., Jr. Focusing the metaphor: Plant root foraging behaviour. Trends Ecol. Evol. 2009, 24, 419-426. [CrossRef] [PubMed]

28. Dicke, M.; Baldwin, I.T. The evolutionary context for herbivore-induced plant volatiles: Beyond the "cry for help". Trends Plant Sci. 2010, 15, 167-175. [CrossRef]

29. Erb, M.; Veyrat, N.; Robert, C.A.M.; Xu, H.; Frey, M.; Ton, J.; Turlings, T.C.J. Indole is an essential herbivore-induced volatile priming signal in maize. Nat. Commun. 2015, 6. [CrossRef]

30. Gfeller, V.; Huber, M.; Foerster, C.; Huang, W.; Koellner, T.G.; Erb, M. Root volatiles in plant-plant interactions I: High root sesquiterpene release is associated with increased germination and growth of plant neighbours. Plant Cell Environ. 2019, 42, 1950-1963. [CrossRef]

31. Molish, H. Der Einfluss Einer Pflanze auf die Andere-Allelopathie; Gustav Fischer Verlag: Jena, Germany, 1937.

32. Simms, E.L.; Rausher, M.D. Costs and benefits of plant resistance to herbivory. Am. Nat. 1987, 130, 570-581. [CrossRef]

33. Kim, J.; Felton, G.W. Priming of antiherbivore defensive responses in plants. Insect Sci. 2013, 20, 273-285. [CrossRef] [PubMed]

34. Langenheim, J.H. Higher plant terpenoids: A phytocentric overview of their ecological roles. J. Chem. Ecol. 1994, 20, 1223-1280. [CrossRef] [PubMed]

35. Ameye, M.; Audenaert, K.; De Zutter, N.; Steppe, K.; Van Meulebroek, L.; Vanhaecke, L.; De Vleesschauwer, D.; Haesaert, G.; Smagghe, G. Priming of wheat with the green leaf volatile Z-3-hexenyl acetate enhances defense against fusarium graminearum but boosts deoxynivalenol production. Plant Physiol. 2015, 167, 1671-1684. [CrossRef]

36. Siri-Udom, S.; Suwannarach, N.; Lumyong, S. Applications of volatile compounds acquired from Muscodor heveae against white root rot disease in rubber trees (Hevea brasiliensis Mull. Arg.) and relevant allelopathy effects. Fungal Biol. 2017, 121, 573-581. [CrossRef]

37. Lerdau, M.; Gray, D. Ecology and evolution of light-dependent and light-independent phytogenic volatile organic carbon. New Phytol. 2003, 157, 199-211. [CrossRef]

38. Cofer, T.M.; Engelberth, M.; Engelberth, J. Green leaf volatiles protect maize (Zea mays) seedlings against damage from cold stress. Plant Cell Environ. 2018, 41, 1673-1682. [CrossRef]

39. Muller, C.H.; Muller, W.H.; Haines, B.L. Volatile growth Inhibitors produced by aromatic shrubs. Science 1964, 143, 471-473. [CrossRef] [PubMed]

40. Muller, C.H. Inhibitory terpenes volatilized from salvia shrubs. Bull. Torrey Bot. Club 1965, 92, 38-45. [CrossRef]

41. Abrahim, D.; Braguini, W.L.; Kelmer-Bracht, A.M.; Ishii-Iwamoto, E.L. Effects of four monoterpenes on germination, primary root growth, and mitochondrial respiration of maize. J. Chem. Ecol. 2000, 26, 611-624. [CrossRef]

42. Norton, J.M.; Harman, G.E. Responses of soil microorganisms to volatile exudates from germinating pea seeds. Can. J. Bot. 1985 63, 1040-1045. [CrossRef]

43. Won Yun, K.; Kil, B.S.; Han, D.M. Phytotoxic and antimicrobial activity of volatile constituents of Artemisia princeps var. orientalis. J. Chem. Ecol. 1993, 19, 2757-2766. [CrossRef] [PubMed]

44. Jassbi, A.R.; Zamanizadehnajari, S.; Baldwin, I.T. Phytotoxic volatiles in the roots and shoots of Artemisia tridentata as detected by headspace solid-phase microextraction and gas chromatographic-mass spectrometry analysis. J. Chem. Ecol. 2010, 36, 1398-1407. [CrossRef]

45. Hütsch, B.W.; Augustin, J.; Merbach, W. Plant rhizodeposition-An important source for carbon turnover in soils. J. Plant Nutr. Soil Sci. 2002, 165, 397-407. [CrossRef]

46. Lin, C.; Owen, S.M.; Peñuelas, J. Volatile organic compounds in the roots and rhizosphere of Pinus spp. Soil Biol. Biochem. 2007, 39, 951-960. [CrossRef]

47. Delory, B.M.; Delaplace, P.; Fauconnier, M.-L.; du Jardin, P. Root-emitted volatile organic compounds: Can they mediate belowground plant-plant interactions? Plant Soil 2016, 402, 1-26. [CrossRef]

48. Fitter, A. Making allelopathy respectable. Science 2003, 301, 1337-1338. [CrossRef] [PubMed]

49. Brilli, F.; Loreto, F.; Baccelli, I. Exploiting plant volatile organic compounds (VOCs) in agriculture to Improve sustainable defense strategies and productivity of crops. Front. Plant Sci. 2019, 10. [CrossRef]

50. Oleszek, W. Allelopathic effects of volatiles from some Cruciferae species on lettuce, barnyard grass and wheat growth. Plant Soil 1987, 102, 271-273. [CrossRef]

51. Romagni, J.G.; Allen, S.N.; Dayan, F.E. Allelopathic effects of volatile cineoles on two weedy plant species. J. Chem. Ecol. 2000, 26, 303-313. [CrossRef]

52. Schmidt-Silva, V.; Pawlowski, Â.; Kaltchuk-Santos, E.; Zini, C.; Soares, G. Cytotoxicity of essential oils from two species of Heterothalamus (Asteraceae). Aust. J. Bot. 2011, 59, 682-691. [CrossRef] 
53. Cheng, F.; Cheng, Z.; Meng, H.; Tang, X. The garlic allelochemical diallyl disulfide affects tomato root growth by influencing cell division, phytohormone balance and expansin gene expression. Front. Plant Sci. 2016, 7, 1199. [CrossRef]

54. Cheng, F.; Cheng, Z.-H.; Meng, H.-W. Transcriptomic insights into the allelopathic effects of the garlic allelochemical diallyl disulfide on tomato roots. Sci. Rep. 2016, 6, 38902. [CrossRef]

55. Kim, Y.S.; Kil, B.-S. Allelopathic effects of some volatile substances from the tomato plant. J. Crop Prod. 2001, 4, 313-321. [CrossRef]

56. Alves, M.d.C.S.; Medeiros Filho, S.; Innecco, R.; Torres, S.B. Alelopatia de extratos voláteis na germinação de sementes e no comprimento da raiz de alface. Pesqui. Agropecuária Bras. 2004, 39, 1083-1086. [CrossRef]

57. Norsworthy, J.K.; Meehan, J.T. Use of isothiocyanates for suppression of Palmer amaranth (Amaranthus palmeri), pitted morningglory (Ipomoea lacunosa), and yellow nutsedge (Cyperus esculentus). Weed Sci. 2017, 53, 884-890. [CrossRef]

58. Horiuchi, J.-i.; Badri, D.V.; Kimball, B.A.; Negre, F.; Dudareva, N.; Paschke, M.W.; Vivanco, J.M. The floral volatile, methyl benzoate, from snapdragon (Antirrhinum majus) triggers phytotoxic effects in Arabidopsis thaliana. Planta 2007, 226, 1-10. [CrossRef] [PubMed]

59. Silva, E.R.; Overbeck, G.E.; Soares, G.L.G. Phytotoxicity of volatiles from fresh and dry leaves of two Asteraceae shrubs: Evaluation of seasonal effects. S. Afr. J. Bot. 2014, 93, 14-18. [CrossRef]

60. Souza-Alonso, P.; Novoa, A.; González, L. Soil biochemical alterations and microbial community responses under Acacia dealbata Link invasion. Soil Biol. Biochem. 2014, 79, 100-108. [CrossRef]

61. Haramoto, E.R.; Gallandt, E.R. Brassica cover cropping for weed management: A review. Renew. Agric. Food Syst. 2007, 19, 187-198. [CrossRef]

62. Morra, M.J.; Kirkegaard, J.A. Isothiocyanate release from soil-incorporated Brassica tissues. Soil Biol. Biochem. 2002, 34, 1683-1690. [CrossRef]

63. Santonja, M.; Bousquet-Mélou, A.; Greff, S.; Ormeño, E.; Fernandez, C. Allelopathic effects of volatile organic compounds released from Pinus halepensis needles and roots. Ecol. Evol. 2019, 9, 8201-8213. [CrossRef]

64. Ren, K.; Hayat, S.; Qi, X.; Liu, T.; Cheng, Z. The garlic allelochemical DADS influences cucumber root growth involved in regulating hormone levels and modulating cell cycling. J. Plant Physiol. 2018, 230, 51-60. [CrossRef]

65. Wei, C.; Zhou, S.; Li, W.; Jiang, C.; Yang, W.; Han, C.; Zhang, C.; Shao, H. Chemical composition and allelopathic, phytotoxic and pesticidal activities of Atriplex cana Ledeb. (Amaranthaceae) essential oil. Chem. Biodivers. 2019, 16, e1800595. [CrossRef]

66. Effah, E.; Holopainen, J.K.; McCormick, A.C. Potential roles of volatile organic compounds in plant competition. Perspect. Plant Ecol. Evol. Syst. 2019, 38, 58-63. [CrossRef]

67. Macias, F.A.; Molinillo, J.M.; Varela, R.M.; Galindo, J.C. Allelopathy-A natural alternative for weed control. Pest Manag Sci 2007, 63, 327-348. [CrossRef] [PubMed]

68. Luiza Ishii-Iwamoto, E.; Marusa Pergo Coelho, E.; Reis, B.; Sebastiao Moscheta, I.; Moacir Bonato, C. Effects of monoterpenes on physiological processes during seed germination and seedling growth. Curr. Bioact. Compd. 2012, 8, 50-64. [CrossRef]

69. Arroyo, A.I.; Pueyo, Y.; Pellissier, F.; Ramos, J.; Espinosa-Ruiz, A.; Millery, A.; Alados, C.L. Phytotoxic effects of volatile and water soluble chemicals of Artemisia herba-alba. J. Arid Environ. 2018, 151, 1-8. [CrossRef]

70. Runyon, J.B.; Mescher, M.C.; De Moraes, C.M. Volatile chemical cues guide host location and host selection by parasitic plants. Science 2006, 313, 1964-1967. [CrossRef] [PubMed]

71. Hunt, N.D.; Hill, J.D.; Liebman, M. Reducing freshwater toxicity while maintaining weed control, profits, and productivity: Effects of increased crop rotation diversity and reduced herbicide usage. Environ. Sci. Technol. 2017, 51, 1707-1717. [CrossRef]

72. Arimura, G.-i.; Shiojiri, K.; Karban, R. Acquired immunity to herbivory and allelopathy caused by airborne plant emissions. Phytochemistry 2010, 71, 1642-1649. [CrossRef]

73. Verdeguer, M.; Blázquez, M.; Boira, H. Phytotoxic effects of Lantana camara, Eucalyptus camaldulensis and Eriocephalus africanus essential oils in weeds of Mediterranean summer crops. Biochem. Syst. Ecol. 2009, 37, 362-369. [CrossRef]

74. Benvenuti, S.; Cioni, P.L.; Flamini, G.; Pardossi, A. Weeds for weed control: Asteraceae essential oils as natural herbicides. Weed Res. 2017, 57, 342-353. [CrossRef]

75. Mushtaq, W.; Ain, Q.; Siddiqui, M.B.; Alharby, H.; Hakeem, K.R. Allelochemicals change macromolecular content of some selected weeds. S. Afr. J. Bot. 2020, 130, 177-184. [CrossRef]

76. Fahey, J.W.; Zalcmann, A.T.; Talalay, P. The chemical diversity and distribution of glucosinolates and isothiocyanates among plants. Phytochemistry 2001, 56, 5-51. [CrossRef]

77. Halkier, B.A.; Gershenzon, J. Biology and biochemistry of glucosinolates. Annu. Rev. Plant Biol. 2006, 57, 303-333. [CrossRef] [PubMed]

78. Petersen, J.; Belz, R.; Walker, F.; Hurle, K. Weed suppression by release of Isothiocyanates from turnip-rape mulch. Agron. J. 2001, 93, 37-43. [CrossRef]

79. Pardo-Muras, M.; Puig, C.G.; López-Nogueira, A.; Cavaleiro, C.; Pedrol, N. On the bioherbicide potential of Ulex europaeus and Cytisus scoparius: Profiles of volatile organic compounds and their phytotoxic effects. PLoS ONE 2018, 13, e0205997. [CrossRef]

80. Pardo-Muras, M.; Puig, C.G.; Pedrol, N. Cytisus scoparius and Ulex europaeus produce volatile organic compounds with powerful synergistic herbicidal effects. Molecules 2019, 24, 4539. [CrossRef] [PubMed]

81. Vokou, D.; Douvli, P.; Blionis, G.J.; Halley, J.M. Effects of monoterpenoids, acting alone or in pairs, on seed germination and subsequent seedling growth. J. Chem. Ecol. 2003, 29, 2281-2301. [CrossRef] 
82. Barney, J.N.; Sparks, J.P.; Greenberg, J.; Whitlow, T.H.; Guenther, A. Biogenic volatile organic compounds from an invasive species: Impacts on plant-plant interactions. Plant Ecol. 2009, 203, 195-205. [CrossRef]

83. Campbell, M.; Segear, E.; Beers, L.; Knauber, D.; Suttle, J. Dormancy in potato tuber meristems: Chemically induced cessation in dormancy matches the natural process based on transcript profiles. Funct. Integr. Genom. 2008, 8, 317-328. [CrossRef] [PubMed]

84. Hosoki, T.; Hiura, H.; Hamada, M. Breaking bud dormancy in corms, tubers, and trees with sulfur-containing compounds. HortScience 1985, 20, 290-291.

85. Hosoki, T. Breaking bud dormancy in corms and trees with sulfide compounds in garlic and horseradish. HortScience 1986, 21, 114-116.

86. Kubota, N.; Yamane, Y.; Toriu, K.; Kawazu, K.; Higuchi, T.; Nishimura, S. Identification of active substances in garlic responsible for breaking bud dormancy in grapevines. J. Jpn. Soc. Hortic. Sci. 1999, 68(6), 1111-1117. [CrossRef]

87. Shukla, S.; Pandey, S.S.; Chandra, M.; Pandey, A.; Bharti, N.; Barnawal, D.; Chanotiya, C.S.; Tandon, S.; Darokar, M.P.; Kalra, A. Application of essential oils as a natural and alternate method for inhibiting and inducing the sprouting of potato tubers. Food Chem. 2019, 284, 171-179. [CrossRef]

88. Hartmans, K.J.; Diepenhorst, P.; Bakker, W.; Gorris, L.G.M. The use of carvone in agriculture: Sprout suppression of potatoes and antifungal activity against potato tuber and other plant diseases. Ind. Crop. Prod. 1995, 4, 3-13. [CrossRef]

89. Song, X.; Bandara, M.S.; Tanino, K.K. Potato dormancy regulation: Use of essential oils for sprout suppression in potato storage. Fruit Veg. Cereal Sci. Biotechnol 2009, 2, 110-117.

90. Finger, F.L.; Santos, M.M.d.S.; Araujo, F.F.; Lima, P.C.C.; Costa, L.C.d.; França, C.d.F.M.; Queiroz, M.d.C. Action of essential oils on sprouting of non-dormant potato tubers. Braz. Arch. Biol. Technol. 2018, 61. [CrossRef]

91. Owolabi, M.S.; Olowu, R.A.; Lajide, L.; Oladimeji, M.O.; Padilla-Camberos, E.; Flores-Fernández, J.M. Inhibition of potato tuber sprouting during storage by the controlled release of essential oil using a wick application method. Ind. Crop. Prod. 2013, 45, 83-87. [CrossRef]

92. Komai, K.; Tang, C.-S. A chemotype of Cyperus rotundus in Hawaii. Phytochemistry 1989, 28, 1883-1886. [CrossRef]

93. Neri, F.; Mari, M.; Brigati, S.; Bertolini, P. Fungicidal activity of plant volatile compounds for controlling Monilinia laxa in stone fruit. Plant Dis. 2007, 91, 30-35. [CrossRef] [PubMed]

94. Da Silva, A.C.; de Souza, P.E.; Amaral, D.C.; Zeviani, W.M.; Brasil Pereira Pinto, J.E. Essential oils from Hyptis marrubioides, Aloysia gratissima and Cordia verbenacea reduce the progress of Asian soybean rust. Acta Sci. Agron. 2014, 36, 159-166. [CrossRef]

95. Rienth, M.; Crovadore, J.; Ghaffari, S.; Lefort, F. Oregano essential oil vapour prevents Plasmopara viticola infection in grapevine (Vitis Vinifera) and primes plant immunity mechanisms. PLoS ONE 2019, 14, e222854. [CrossRef] [PubMed]

96. Asthana, A.; Tripathi, N.N.; Dixit, S.N. Fungitoxic and phytotoxic studies with essential oil of Ocimum adscendens. J. Phytopathol. 1986, 117, 152-159. [CrossRef]

97. Chaturvedi, R.; Dikshit, A.; Dixit, S.N. Adenocalymma allicea, a new source of a natural fungitoxicant. Trop. Agric. 1987, 64, 318-322.

98. Dube, S.; Upadhyay, P.D.; Tripathi, S.C. Antifungal, physicochemical, and insect-repelling activity of the essential oil of Ocimum basilicum. Can. J. Bot. 1989, 67, 2085-2087. [CrossRef]

99. Wang, C.; Zhang, J.; Chen, H.; Fan, Y.; Shi, Z. Antifungal activity of eugenol against Botrytis cinerea. Trop. Plant Pathol. 2010, 35, 137-143. [CrossRef]

100. Rao, P.V.; Gan, S.H. Cinnamon: A multifaceted medicinal plant. Evid Based Complement Altern. Med. 2014, 2014, 642942. [CrossRef]

101. Quintana-Rodriguez, E.; Rivera-Macias, L.E.; Adame-Alvarez, R.M.; Torres, J.M.; Heil, M. Shared weapons in fungus-fungus and fungus-plant interactions? Volatile organic compounds of plant or fungal origin exert direct antifungal activity in vitro. Fungal Ecol. 2018, 33, 115-121. [CrossRef]

102. Mohammad, S.F.; Woodward, S.C. Characterization of a potent inhibitor of platelet aggregation and release reaction isolated from Allium sativum (Garlic). Thromb. Res. 1986, 44, 793-806. [CrossRef]

103. Yang, F.; Liu, X.; Wang, H.; Deng, R.; Yu, H.; Cheng, Z. Identification and allelopathy of green garlic (Allium sativum L.) volatiles on scavenging of cucumber (Cucumis sativus L.) reactive oxygen species. Molecules 2019, 24, 3263. [CrossRef] [PubMed]

104. Sekine, T.; Sugano, M.; Majid, A.; Fujii, Y. Antifungal effects of volatile compounds from black zira (Bunium persicum) and other spices and herbs. J. Chem. Ecol. 2007, 33, 2123-2132. [CrossRef] [PubMed]

105. Mandal, S.; Mandal, M. Coriander (Coriandrum sativum L.) essential oil: Chemistry and biological activity. Asian Pac. J. Trop. Biomed. 2015, 5, 421-428. [CrossRef]

106. Friberg, M.; Schwind, C.; Roark, L.C.; Raguso, R.A.; Thompson, J.N. Floral scent contributes to interaction specificity in coevolving plants and their insect pollinators. J. Chem. Ecol. 2014, 40, 955-965. [CrossRef] [PubMed]

107. Yazaki, K.; Arimura, G.-i.; Ohnishi, T. 'Hidden' terpenoids in plants: Their biosynthesis, localization and ecological roles. Plant Cell Physiol. 2017, 58, 1615-1621. [CrossRef] [PubMed]

108. Alborn, H.; Turlings, T.; Jones, T.H.; Stenhagen, G.; Loughrin, J.; Tumlinson, J. An elicitor of plant volatiles from beet armyworm oral secretion. Science 1997, 276, 945-949. [CrossRef]

109. Degenhardt, J.; Hiltpold, I.; Köllner, T.G.; Frey, M.; Gierl, A.; Gershenzon, J.; Hibbard, B.E.; Ellersieck, M.R.; Turlings, T.C.J. Restoring a maize root signal that attracts insect-killing nematodes to control a major pest. Proc. Natl. Acad. Sci. USA 2009, 106, 13213-13218. [CrossRef] [PubMed]

110. Li, H.-H.; Nishimura, H.; Hasegawa, K.; Mizutani, J. Allelopathy of Sasa cernua. J. Chem. Ecol. 1992, 18, 1785-1796. [CrossRef] 
111. Cheng, F.; Cheng, Z. Research progress on the use of plant allelopathy in agriculture and the physiological and ecological mechanisms of allelopathy. Front. Plant Sci. 2015, 6. [CrossRef]

112. Weaver, T.; Klarich, D. Allelopathic effects of volatile substances from Artemisia tridentata Nutt. Am. Midl. Nat. 1977, 92, 508-512. [CrossRef]

113. Einhellig, F.A. Mechanism of Action of Allelochemicals in Allelopathy; ACS Publications: Washington, DC, USA, 1995.

114. Kohli, R.K.; Batish, D.R.; Singh, H.P. Eucalypt oils for the control of Parthenium (Parthenium hysterophorus L.). Crop Prot. 1998, 17, 119-122. [CrossRef]

115. Einhellig, F.A.; Rasmussen, J.A. Effects of three phenolic acids on chlorophyll content and growth of soybean and grain sorghum seedlings. J. Chem. Ecol. 1979, 5, 815-824. [CrossRef]

116. Sharkey, T.D.; Yeh, S. Isoprene emission from plants. Annu. Rev. Plant Biol. 2001, 52, 407-436. [CrossRef]

117. Kaur, S.; Singh, H.P.; Batish, D.R.; Kohli, R.K. Chemical characterization and allelopathic potential of volatile oil of Eucalyptus tereticornis against Amaranthus viridis. J. Plant Interact. 2011, 6, 297-302. [CrossRef]

118. Tsubo, M.; Nishihara, E.; Nakamatsu, K.; Cheng, Y.; Shinoda, M. Plant volatiles inhibit restoration of plant species communities in dry grassland. Basic Appl. Ecol. 2012, 13, 76-84. [CrossRef]

119. Yang, X.; Deng, S.; De Philippis, R.; Chen, L.; Hu, C.; Zhang, W. Chemical composition of volatile oil from Artemisia ordosica and its allelopathic effects on desert soil microalgae, Palmellococcus miniatus. Plant Physiol. Biochem. 2012, 51, 153-158. [CrossRef] [PubMed]

120. Zhao, J.; Yang, L.; Zhou, L.; Bai, Y.; Wang, B.; Hou, P.; Xu, Q.; Yang, W.; Zuo, Z. Inhibitory effects of eucalyptol and limonene on the photosynthetic abilities in Chlorella vulgaris (Chlorophyceae). Phycologia 2016, 55, 696-702. [CrossRef]

121. Tsai, C.W.; Yang, J.J.; Chen, H.W.; Sheen, L.Y.; Lii, C.K. Garlic organosulfur compounds upregulate the expression of the pi class of glutathione S-transferase in rat primary hepatocytes. J. Nutr. 2005, 135, 2560-2565. [CrossRef]

122. Hsiung, Y.-C.; Chen, Y.-A.; Chen, S.-Y.; Chi, W.-C.; Lee, R.-H.; Chiang, T.-Y.; Huang, H.-J. Volatilized myrcene inhibits growth and activates defense responses in rice roots. Acta Physiol. Plant. 2013, 35, 2475-2482. [CrossRef]

123. Mutlu, S.; Atici, Ö.; Esim, N.; Mete, E. Essential oils of catmint (Nepeta meyeri Benth.) induce oxidative stress in early seedlings of various weed species. Acta Physiol. Plant. 2011, 33, 943-951. [CrossRef]

124. Jin, P.; Wu, X.; Xu, F.; Wang, X.; Wang, J.; Zheng, Y. Enhancing antioxidant capacity and reducing decay of Chinese bayberries by essential oils. J. Agric. Food Chem. 2012, 60, 3769-3775. [CrossRef]

125. Baldwin, I.T.; Halitschke, R.; Paschold, A.; von Dahl, C.C.; Preston, C.A. Volatile signaling in plant-plant interactions: “Talking trees" in the genomics era. Science 2006, 311, 812-815. [CrossRef]

126. Heil, M.; Silva Bueno, J.C. Within-plant signaling by volatiles leads to induction and priming of an indirect plant defense in nature. Proc. Natl. Acad. Sci. USA 2007, 104, 5467-5472. [CrossRef]

127. Kessler, A.; Halitschke, R.; Diezel, C.; Baldwin, I.T. Priming of plant defense responses in nature by airborne signaling between Artemisia tridentata and Nicotiana attenuata. Oecologia 2006, 148, 280-292. [CrossRef]

128. Ton, J.; D'Alessandro, M.; Jourdie, V.; Jakab, G.; Karlen, D.; Held, M.; Mauch-Mani, B.; Turlings, T.C.J. Priming by airborne signals boosts direct and indirect resistance in maize. Plant J. 2007, 49, 16-26. [CrossRef]

129. Heil, M.; Ton, J. Long-distance signalling in plant defence. Trends Plant Sci. 2008, 13, 264-272. [CrossRef]

130. Biedrzycki, M.L.; Bais, H.P. Kin recognition in plants: A mysterious behaviour unsolved. J. Exp. Bot. 2010, 61, 4123-4128. [CrossRef]

131. Broz, A.K.; Broeckling, C.D.; De-la-Peña, C.; Lewis, M.R.; Greene, E.; Callaway, R.M.; Sumner, L.W.; Vivanco, J.M. Plant neighbor identity influences plant biochemistry and physiology related to defense. BMC Plant Biol. 2010, 10, 115. [CrossRef] [PubMed]

132. Chen, B.J.; During, H.J.; Anten, N.P. Detect thy neighbor: Identity recognition at the root level in plants. Plant Sci. Int. J. Exp. Plant Biol. 2012, 195, 157-167. [CrossRef] [PubMed]

133. Karban, R.; Shiojiri, K. Self-recognition affects plant communication and defense. Ecol. Lett. 2009, 12, 502-506. [CrossRef] [PubMed]

134. Masclaux, F.; Hammond, R.L.; Meunier, J.; Gouhier-Darimont, C.; Keller, L.; Reymond, P. Competitive ability not kinship affects growth of Arabidopsis thaliana accessions. New Phytol. 2010, 185, 322-331. [CrossRef]

135. Milla, R.; Forero, D.M.; Escudero, A.; Iriondo, J.M. Growing with siblings: A common ground for cooperation or for fiercer competition among plants? Proc. R. Soc. B Biol. Sci. 2009, 276, 2531-2540. [CrossRef] [PubMed]

136. Yang, X.-F.; Li, L.-L.; Xu, Y.; Kong, C.-H. Kin recognition in rice (Oryza sativa) lines. New Phytol. 2018, 220, 567-578. [CrossRef] [PubMed]

137. Torices, R.; Gómez, J.M.; Pannell, J.R. Kin discrimination allows plants to modify investment towards pollinator attraction. Nat. Commun. 2018, 9, 2018. [CrossRef] [PubMed]

138. Brooks, G.T. Comprehensive insect physiology, biochemistry and pharmacology: Edited by G. A. Kerkut and L. I. Gilbert. Pergamon Press, Oxford. 1985. 13 Volumes. 8200 pp approx. £1700.00/\$2750.00. ISBN 008026850 1. Insect Biochem. 1985, 15, i-xiv. [CrossRef]

139. Kimparis, A.; Siatis, N.; Daferera, D.; Tarantilis, P.; Pappas, C.; Polissiou, M. Comparison of distillation and ultrasound-assisted extraction methods for the isolation of sensitive aroma compounds from garlic (Allium sativum). Ultrason. Sonochem. 2006, 13, 54-60. [CrossRef] 
140. Lee, S.N.; Kim, N.S.; Lee, D.S. Comparative study of extraction techniques for determination of garlic flavor components by gas chromatography-mass spectrometry. Anal. Bioanal. Chem. 2003, 377, 749-756. [CrossRef]

141. Mutarutwa, D.; Navarini, L.; Lonzarich, V.; Compagnone, D.; Pittia, P. GC-MS aroma characterization of vegetable matrices: Focus on 3-alkyl-2-methoxypyrazines. J. Mass Spectrom. 2018, 53, 871-881. [CrossRef]

142. Sgorbini, B.; Cagliero, C.; Liberto, E.; Rubiolo, P.; Bicchi, C.; Cordero, C. Strategies for accurate quantitation of volatiles from foods and plant-origin materials: A challenging task. J. Agric. Food Chem. 2019, 67, 1619-1630. [CrossRef]

143. Verpoorte, R.; Choi, Y.H.; Kim, H.K. NMR-based metabolomics at work in phytochemistry. Phytochem. Rev. 2007, 6, 3-14. [CrossRef]

144. Marshall, T.L.; Chaffin, C.T.; Makepeace, V.D.; Hoffman, R.M.; Hammaker, R.M.; Fateley, W.G.; Saarinen, P.; Kauppinen, J. Investigation of the effects of resolution on the performance of classical least-squares (CLS) spectral interpretation programs when applied to volatile organic compounds (VOCs) of interest in remote sensing using open-air long-path Fourier transform infrared (FT-IR) spectrometry. J. Mol. Struct. 1994, 324, 19-28. [CrossRef]

145. Stierlin, É.; Nicolè, F.; Fernandez, X.; Michel, T. Development of a headspace solid-phase microextraction gas chromatographymass spectrometry method to study volatile organic compounds (VOCs) emitted by lavender roots. Chem. Biodivers. 2019, 16, e1900280. [CrossRef] [PubMed]

146. Danner, H.; Samudrala, D.; Cristescu, S.M.; Van Dam, N.M. Tracing hidden herbivores: Time-resolved non-invasive analysis of belowground volatiles by proton-transfer-reaction mass spectrometry (PTR-MS). J. Chem. Ecol. 2012, 38, 785-794. [CrossRef] [PubMed]

147. Capozzi, V.; Lonzarich, V.; Khomenko, I.; Cappellin, L.; Navarini, L.; Biasioli, F. Unveiling the molecular basis of mascarpone cheese aroma: VOCs analysis by SPME-GC/MS and PTR-ToF-MS. Molecules 2020, 25, 1242. [CrossRef]

148. Lebanov, L.; Ghiasvand, A.; Paull, B. Data handling and data analysis in metabolomic studies of essential oils using GC-MS. J. Chromatogr. A 2021, 1640, 461896. [CrossRef]

149. Majchrzak, T.; Wojnowski, W.; Lubinska-Szczygeł, M.; Różańska, A.; Namieśnik, J.; Dymerski, T. PTR-MS and GC-MS as complementary techniques for analysis of volatiles: A tutorial review. Anal. Chim. Acta 2018, 1035, 1-13. [CrossRef]

150. Hare, J.D. Ontogeny and season constrain the production of herbivore-inducible plant volatiles in the field. J. Chem. Ecol. 2010, 36, 1363-1374. [CrossRef] 